\title{
Illustrations and Tables
}

FIGURES

1. "Roman Catholics, Jews, and Protestants in New York City, 1909

MAPS

1. Roman Catholics as a percentage of all American religious adherents, 1926

2. Early liberalizers

3. Unofficial supporters 106

4. Critics (excluding Roman Catholics) 142

5. Silent groups 155

\section{TABLES}

1. Sample of religious denominations

2. Demographics of American religious denominations circa 1926 
3. Key words searched 20

4. Stances on birth control by belief in race suicide and the social gospel 27

5. Early religious activism in the American religious field 36

6. Religious identity and membership in the American religious field circa $1930 \quad 50$

7. Measures of feminism among American religious groups circa $1930 \quad 60$

8. Support for eugenics in the American religious field circa $1930 \quad 68$

9. American religious denominations then and now 178 